\title{
Os vetores de expansão da atividade imobiliária em Belo Horizonte - 1994-2003
}

Luiz. Andrés Paixão
Coordenação de Serviços e Comércio/IBGE
Pedro Abramo
IPPUR/UFRJ

\section{Palauras-chave}

economia urbana, economia pós-keynesiana, Belo Horizonte.

Classificação JEL R20; R21.

\section{Key word}

urban economics, post post-Keynesian economics, Belo Horizonte.

JEL Classification R20; R21.

\section{Resumo}

Este artigo discute a estruturação urbana da cidade de Belo Horizonte no período 19942003. Partindo de um arcabouço metodológico pós-keynesiano para a economia urbana, esboçamos os principais vetores de atuação da atividade imobiliária na cidade de Belo Horizonte. Concluímos que a atividade imobiliária residencial tem abandonado a região Sul e Nordeste e se concentrado na região da Pampulha. A atividade imobiliária comercial, por sua vez, tem deixado a região Centro para se concentrar na região Sul.

\section{Abstract}

This article discusses the shifts in the urban structure of the city of Belo Horizonte in the period between 1994 and 2003. Departing from a post-Keynesian methodological basis, we outlined the main vectors of real estate activity in Belo Horizonte. We conclude that residential real estate activity has been leaving the South and Northeast regions and concentrating on the Pampulha region, whereas commercial real estate activity has been gradually abandoning the city centre to become established in the Southern region. 


\section{1_O modelo teórico}

\subsection{A economia heterodoxa: a centralidade do conceito de convenção}

Estabelecer uma teoria econômica alternativa ao mainstream é tarefa das escolas de pensamento heterodoxo. Desde os anos 1980, diversas leituras metodológicas dos escritos filosóficos de Keynes vêm sendo feitas, podendo servir para a construção de um paradigma teórico metodológico alternativo ao neoclássico. ${ }^{1}$ Alguns autores, como Davis (1994) e Andrade (2004), defendem que o conceito de convenção é central para se entender o projeto teórico alternativo de Keynes. O desenvolvimento do significado e a aplicação do conceito de convenção é uma tarefa importante para se ter uma proposta teórica robusta e, ao mesmo tempo, alternativa àquela ditada pela economia ortodoxa.

O conceito de convenção foi gestado ao longo dos escritos de Keynes (Andrade, 2003). Primeiramente, apareceu na obra Teoria geral (1936) para explicar o comportamento do investidor no mercado de ações. Posteriormente, o conceito aparece no artigo "Algumas conseqüências de uma população em declínio" (1937), tendo sua versão mais acabada no artigo "A teoria geral do emprego" (1937). Segundo a abordagem de Keynes, a convenção é a regra de ação do indivíduo dentro do sistema econômico ao qual está inserido, sendo essa uma teoria da ação racional em um ambiente de incerteza, no qual o tempo é histórico e cronológico; e cada decisão econômica tem caráter crucial.

A ação do indivíduo no mercado não é marcada pela limpidez da hipótese do conhecimento perfeito, no qual cada ator sabe ao certo o quanto de utilidade vai extrair, dada sua renda, devido ao perfeito funcionamento do sistema de preços. Keynes trabatha em um mundo em que o desconhecimento (quanto ao futuro) é a regra e, por esse motivo, as formas de agir são construídas, não da observação do sistema de preços apenas, mas valendo-se da observação das regras e condutas sociais que surgem nas relações humanas, inclusive nas de mercado. O conceito de convenção é assim proposto por Keynes:

1. Supomos que o presente constitui um guia muito mais prestimoso para o futuro do que um ingênuo exame da experiência passada mostraria até hoje. Em outras palavras, ignoramos em grande parte a perspectiva de mudanças futuras, acerca de cujo caráter real nada sabemos; 2. Supomos que o vigente estado de opinião, expresso em preços e no caráter da produção existente, baseia-se num sumário correto das futuras perspectivas, de maneira que podemos aceitá-lo como tal, a menos que algo novo e importante penetre no quadro. 3. Por sa-
Andrade (2000) aponta as teses de Carabelli e O’Donnel como marco inicial da discussão. 
ber que a opinião individual carece de valor, procuramos voltar-nos para a opinião do resto do mundo, que talvez esteja mais bem informado. Isto é, procuramos conformar-nos ao comportamento da maioria ou da média. A psicologia de uma sociedade de individuos, cada um dos quais procurando copiar os outros, leva ao que podemos denominar rigorosamente de opinião convencional (Keynes, 1984, p. 172).

De acordo com Andrade (2003), o conceito de convenção tem duplo significado. É uma condição estrutural que serve como modelo de ação para o indivíduo. A convenção como estrutura é um acordo tácito e implícito - semiconsciente - entre os atores econômicos que serve como guia para a ação individual. Ela tem um importante caráter informacional, dado que a observação das relações sociais serve como fonte de aprendizado, a qual o indivíduo recorre para tomar decisões econômicas. Como forma de ação, a convenção - atitudes convencionais - implica uma expectativa de reciprocidade. Um indivíduo age de uma maneira porque espera que os outros também ajam de maneira semelhante. Essa idéia de correspondência entre as ações individuais é a chave para explicar um ambiente econômico estável e sujeito a regularidades.

Andrade (2003) identifica cinco características nas convenções: estabilidade, in- tersubjetividade, precariedade, dinamismo e diferenciabilidade. As convenções são estáveis, uma vez que se fundam na crença de que determinado estado dos negócios vai se perpetuar indefinidamente. É intersubjetiva, já que é compartilhada pelos diversos atores e reafirmada pelo conjunto de atitudes convencionais. Por se fundar em um acordo implícito e semiconsciente entre os atores, a convenção é precária e pode ser perturbada ou rompida por comportamentos não-convencionais. $\mathrm{O}$ dinamismo da convenção deriva de sua precariedade, dado que os comportamentos não-convencionais podem ocorrer, rompendo antigas convenções - o que leva a um sentimento de fragilidade -, mas abre o espaço para o surgimento de outras convenções. Atitudes do tipo animal spirit de indivíduos que apostam na mudança reforçam o seu caráter dinâmico. O surgimento de outras convenções corresponde ao fenômeno schumpeteriano da "destruição criativa", sendo o comportamento do empresário inovador análogo ao "remar contra a corrente" da atitude animal spirit.

[...] "animal spirits", the impulse to act which drives the behavior of some agents and may give rise to innovation and transformation of settled frameworks - the type of behaviour which motivates, for instance, the Schumpterian entrepeneur. Schumpe- 
ter's account of creative destruction is one of starting points of a theory of conventions, where the properties of precariousness and dynamics are highlighted (Andrade, 2003, p. 14).

Por fim, a diferenciabilidade diz respeito aos diferentes tipos de convenção existentes. Grosso modo, cada relação social teria um tipo de convenção guiando as ações dos atores. Analisaremos, na próxima seção, a convenção urbana, que é o mecanismo que coordena as ações dos atores no mercado de localizações urbanas.

\section{2_A economia urbana heterodoxa: a convenção urbana}

\subsection{1_ A dinâmica do mercado imobiliário}

A atividade imobiliária molda o espaço urbano a partir da ação dos empreendedores urbanos. A estruturação urbana é marcada por se configurar em uma constelação de localizações (bairros) homogêneas quanto ao perfil socioeconômico dos seus habitantes. A ação dos empreendedores busca satisfazer o desejo de localização das famílias, que é justamente morar em um bairro junto a famílias de mesmo padrão socioeconômico, usufruindo as externalidades de vizinhança. Não há, porém, nenhum mecanismo formal de coordenação desse mercado. ${ }^{2}$ Para que o desejo de cada família se torne realidade, é preciso que as demais famílias do mesmo tipo tomem a mesma decisão locacional. Já os empreendedores urbanos, para extraírem os ganhos extraordinários (markup urbano), têm de oferecer residência no local em que as famílias abastadas desejam, dado que essa é a demanda solvável. Ou seja, a configuração do espaço urbano está sujeita à incerteza quanto à estruturação urbana futura (incerteza urbana). A escolha residencial pode ser tratada como uma "economia das antecipações", na qual cada ator busca adivinhar o que o outro está pensando que os demais estão pensando. Essa é uma dinâmica auto-referenciada, dado que a confirmação dos julgamentos dos atores reitera os julgamentos emitidos anteriormente (Abramo, 1995a, p. 464).

A convenção urbana é fruto da dinâmica em que as famílias elegem a atuação dos empreendedores urbanos como fonte de informação sobre o futuro da espacialidade urbana. Por arcar com os riscos da atividade imobiliária, o empreendedor é tido como o ator mais informado. $\mathrm{O}$ sinal emitido por esse ator serve como parâmetro orientador das famílias em sua escolha de localização. Os empreendedores, porém, também estão sujeitos à incerteza:

No 'isolamento' do mercado, as famílias podem ter a ilusão (cognitiva) que a oferta

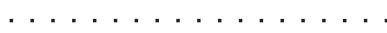

2 A legislação urbanística busca influenciar a ação dos empreendedores urbanos, mas tem um potencial limitado na imposição de uma escolha locacional a estes. 
3 O poder público pode atuar no sentido de diminuir a incerteza urbana a partir de investimentos públicos seletivos que valorizem determinada localização, atraindo famílias abastadas.

A construção de um parque ou de um centro cultural são exemplos desse tipo de investimento. Outra forma de se diminuir a incerteza urbana é a adoção de uma política pública de financiamento imobiliário que inclua famílias de elevado padrão socioeconômico. permanece soberana sobre o mercado residencial [...] Assim, já que todos se encontram no mesmo ambiente de incerteza urbana radical, sua percepsão cognitiva poderá fazer com que as familias creiam que os empreendedores, dado que eles correm aparentemente mais riscos, detêm as informacoões que elas mesmas não dispõem (Abramo, 1995a, p. 473).

O empreendedor urbano reúne, nesse sentido, as características do especulador keynesiano (profissional que guia o mercado), frio e calculista, com o entusiasmo do tipo animal spirit do empresário schumpeteriano, cuja atividade está voltada para a produção e a inovação. Como o especulador, o empreendedor é o profissional do ruído urbano, aquele que vai contra o status quo, emitindo sinais de mudanças. $\mathrm{Na}$ função de empresário schumpeteriano, o empreendedor urbano vai produzir, materialmente, essas mudanças na localização em que se acredita que será habitada pelas famílias abastadas. O empreendedor urbano, portanto, vai com uma "mão" produzir ruídos quanto à escolha residencial das famílias abastadas, destruindo a convenção urbana em vigor, para, com a outra "mão", estabelecer uma nova convenção que resulta em uma nova configuração do espaço intra-urbano. A forma de atuação do empreendedor urbano, que planta inovação e colhe uma nova convenção urbana, serve como estratégia para manter o seu domínio na manipulação da crença dos atores urbanos. Entretanto, a atividade do empreendedor também está sujeita à incerteza. ${ }^{3} \mathrm{~A}$ idéia de que esses profissionais possuem mais informação sobre a localização virtual dos diferentes tipos de família se ergue tão-somente no domínio da crença (Abramo, 1995a, p. 477).

A inovação espacial possibilita ao empreendedor urbano auferir o mark up urbano. O imóvel residencial tem seu valor determinado por suas características físicas (grau de sofisticação) e localização (externalidades de vizinhança). Portanto, a inovação espacial é a diferenciação do produto moradia, que corresponde à produção de imóveis mais sofisticados em novas localizações. Existem dois tipos de inovação espacial: a inovação "radical" e a inovação "local".

A inovação "radical" é a inovação, no sentindo schumpeteriano do termo, na qual os empreendedores escolhem novas localizações para produzir bens imóveis mais sofisticados do que os preexistentes na cidade. A sofisticação do produto serve como isca para atrair as famílias abastadas para essa nova localização. Contudo, ao escolherem uma nova área de atuação, que corresponde a um novo eixo de valorização, os empreendedores urbanos depreciam o es- 
toque imobiliário das demais localizações. Essa depreciação fictícia das localizações é a face urbana do fenômeno da "destruição criativa”, proposto por Schumpeter (1982), não sendo uma depreciação física do imóvel, pelo menos no primeiro momento, mas uma depreciação no perfil social dos moradores da localização. Ao deixarem sua antiga localização, as famílias abastadas abrem espaço para que famílias de um estrato socioeconômico inferior habitem a região preterida, em uma dinâmica que pode, no limite, abranger a totalidade da estrutura urbana.

A inovação "local" corresponde à difusão de inovações radicais passadas em determinadas localizações. A dinâmica da inovação "local" consiste em os empreendedores urbanos escolherem determinadas localizações para replicar um padrão de bem moradia já existente em outras localizações da cidade. Embora não se trate de uma inovação, no sentido schumpeteriano, a inovação "local" representa uma renovação (sofisticação) do estoque imobiliário da localização onde ocorre. A inovação local visa atrair famílias de estratos de rendimento intermediário para a localização, e, quanto maior for o padrão socioeconômico das famílias que os empreendedores pretendem atrair, maior será a sofisticação do bem moradia a ser construído e, conseqüentemente, menor será o gap temporal da imitação. ${ }^{4}$
A dinâmica espacial da inovação "local" é semelhante à da inovação "radical", dado que as famílias de rendimento intermediário, ao deixarem sua localização, abrem espaço para que os imóveis da localização preterida passem a ser habitados por famílias de padrão socioeconômico inferior.

A dinâmica imobiliária, em uma determinada localização, pode ser descrita com base no índice de verticalização-densificação $(D V)$, que representa a convenção urbana quanto ao padrão futuro da ocupação da área. $\mathrm{O}$ indicador $D V$ é uma medida da expectativa quanto ao tipo socioeconômico das famílias que habitarão a localização, materializado pelo tipo de edificação correspondente aos gostos dessas familias. Estabelecida uma convenção urbana, haverá uma corrida dos empreendedores para tornar a ocupação da área igual àquela esperada. À medida que os bens imóveis vão sendo entregues, a densidade real da localização (D) vai se aproximando da virtual $(D V)$. Como o investimento em bens imóveis tem uma inércia temporal, e a atividade dos empreendedores urbanos é autônoma, estes não têm a informação exata de quando devem cessar os investimentos na localização para que as expectativas iniciais sejam realizadas $(D=D V)$. Esquematicamente, à medida que $D$ se aproxima de $D V$, cria-se uma zona fluida, onde duas situações distintas podem ocorrer:

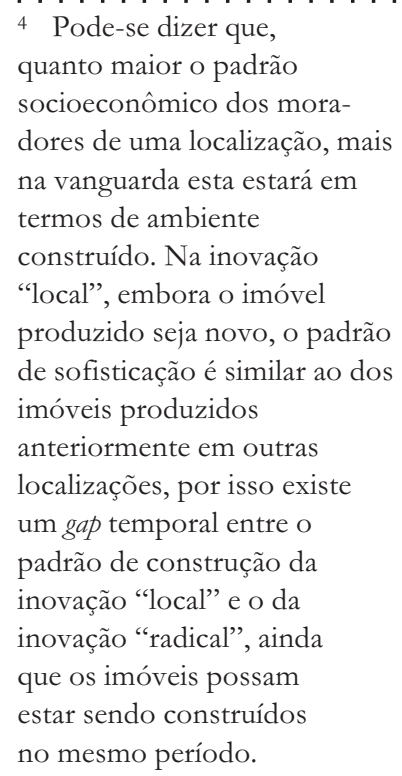


i. os empreendedores continuam a investir na área, tendendo a uma hiperocupação $D>D V$, em que o estoque residencial ultrapassa aquele ditado pela convenção urbana;

ii. os empreendedores cessam o investimento na área, receosos de que outras localidades estejam sendo valorizadas, ou seja, de que já esteja surgindo uma nova convenção. Nesse caso, $D<D V$.

Em ambos os casos, a realidade frustra a crença inicial, destruindo a convenção urbana em vigor, mas abrindo a possibilidade do surgimento de outra convenção para coordenar as decisões locacionais dos atores urbanos. Analisando o padrão de ocupação de cada localização da cidade $(D)$, temos que a natureza dinâmica da convenção urbana é capaz de modificá-lo no tempo. É possível então estabelecer o "ciclo de vida das localizações" que corresponde às alterações no padrão de ocupação pelo qual cada localização da cidade passou ao longo do tempo. A princípio, a localização tende a ter uma ocupação horizontal, com um índice verticalização-densificação (D) baixo. Ao ser eleita como área de atuação da atividade imobiliária, pela convenção urbana, essa localização passa a ser um imenso "canteiro de obras", tendo seu padrão de ocupação alterado, apresentando aumento em $D$. Por fim, o esgotamento da convenção urbana, que direcionou a atividade imobiliária para essa localização, faz com que a localização estabilize em seu novo padrão de ocupação, tornando-se o $D$ estável.

A estabilização do padrão de ocupação de uma localização não significa cessar, por completo, a produção imobiliária. Isso significa que já não é mais possível extrair os ganhos ampliados da atividade imobiliária nessa localização. Por conseqüência, a localização não terá mais a atuação em bloco dos empreendedores urbanos. Existem, portanto, duas formas de se extrair o mark up urbano:

_ Mark up nas áreas de expansão (tipo I): os ganhos da atividade imobiliária são extraídos por um grande número de empreendedores atuando em uma localização da cidade (mark up ampliado). A localização, nesse caso, está passando por mudanças em sua forma de ocupação, graças à atividade em bloco dos empreendedores. O preço do terreno e a sofisticação do produto tendem a não ser constrangimento para os empreendedores. A localização pode ser palco tanto de inovação "radical" quanto de inovação "local". 
- Mark up nas áreas consolidadas (tipo II): nesse caso, a atuação se dá em uma localização que não está sofrendo um boom no mercado primário urbano. Como a área está consolidada, em geral, os preços dos terrenos são altos, e o produto oferecido tende a ser de alto padrão para justificar os custos de aquisição do terreno (mark up de monopólio). A conjunção do alto valor do terreno com a sofisticação do produto impõe uma barreira à entrada para pequenos e médios empreendedores. A localização, nesse caso, é palco apenas de inovação "radical". 5

\subsection{2_ 0 papel do planejamento urbano}

Na seção anterior, modelamos a dinâmica imobiliária, resultante da interação das famílias e empreendedores urbanos no mercado imobiliário, que é responsável pela configuração de estrutura intra-urbana. Existe, todavia, um terceiro ator capaz de influenciar na configuração da ordem urbana, o setor público (poder local). A justificativa para a intervenção do poder local no mercado de localizações é baseada nas falhas de mercado associadas à organização do espaço intra-urbano decorrentes de um mercado imobiliário não regulado. A livre ação das famílias e empreendedores urbanos pode gerar algumas externalidades negativas, isto é, custos sociais cujos mais relevantes são:

\section{Adensamento excessivo do solo urbano em relação à infra-estrutura disponivel; sobre- carga do sistema viário, levando a grandes congestionamentos do tráfego em uma certa área e nas suas vizinhanças; a deterioriza- ção da área urbanizada; e a poluição e a degradação ambiental (Galvão, 2005, p. 27).}

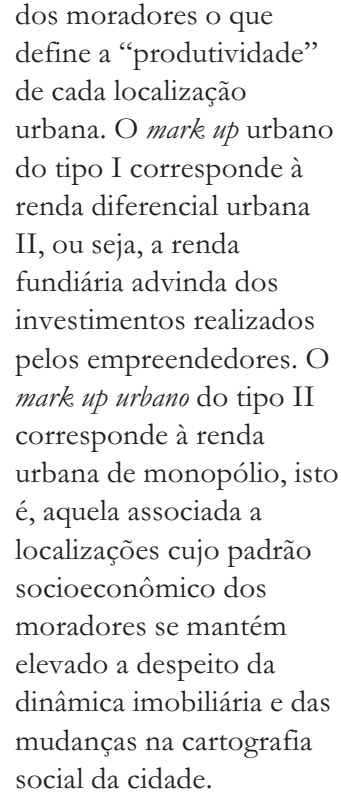


"

6 É importante notar que, havendo expectativa de que exista demanda que arque com os altos preços na localização, o empreendedor vai produzir o bem moradia. $\mathrm{O}$ aumento no preço faz com que a atividade imobiliária só seja rentável nessa localização se for focalizada em demanda de alto poder aquisitivo.

7 A sociedade civil é um grupo difuso que inclui os movimentos sociais urbanos, as famílias que demandam moradia, etc. que nem sempre têm um objetivo comum.
O poder local utiliza do planejamento urbano no intuito de minimizar os custos sociais que podem surgir das decisões locacionais dos atores do mercado imobiliário. O principal instrumento utilizado para esse fim é a lei de zoneamento que estipula localizações que podem ou devem ser adensadas e aquelas localizações que devem ter o adensamento contido ou, em casos extremos, devem ter o adensamento suspenso. $\mathrm{Na}$ tentativa de conter o adensamento em uma determinada localização da cidade, a lei de zoneamento vai impor algum tipo de constrangimento à atuação da atividade imobiliária nessa localização, o que se traduz em maior custo para o empreendedor e conseqüentemente maior preço para o consumidor final, o que tem como efeito diminuir a demanda pelo bem moradia na localização em questão. ${ }^{6}$

A lei de zoneamento é resultado do processo político em que os diversos grupos envolvidos no mercado de localizações têm seus interesses confrontados. Esses grupos de interesse podem ser resumidos em poder local, sociedade civil, ${ }^{7}$ proprietários de terrenos urbanos e empreendedores urbanos. A peça jurídica resultante desse processo é, portanto, um acordo entre as diversas partes e, como tal, está inserida no conceito de convenção urbana.
Em um dado momento do tempo (curto prazo), a Lei de Zoneamento é um dos parâmetros que o empreendedor urbano leva em conta na sua decisão de investimento, tendo esse que se adequar ao zoneamento vigente na localidade em que o investimento será realizado. No longo prazo, a legislação urbanística pode ser alterada graças à pressão dos diferentes grupos de interesse envolvidos na estruturação do espaço intra-urbano. A legislação urbanística como parte da convenção urbana carrega forte conteúdo informacional, conservando os caracteres intersubjetivo (acordo entre as partes) e dinâmico característicos das convenções.

\section{Base de dados e metodologia}

A base de dados utilizada em nossa análise é composta pelos dados de baixas, projetos, transações imobiliárias e estoque imobiliário fornecidos pela Prefeitura Municipal de Belo Horizonte (PBH). As baixas e os projetos foram disponibilizados pela Secretaria Municipal de Regulação Urbana (SMRU), que é responsável por aprovar as novas edificações existentes (baixas) e os projetos para novos empreendimentos (projetos). As baixas e os projetos correspondem aos imóveis residenciais para cada região da cidade. 
As transações imobiliárias foram disponibilizadas pela Secretaria Municipal de Fazenda (SMFA), responsável pela arrecadação do Imposto sobre Transação com Bens Imóveis Inter-Vivos (ITBI), que contém as informações relativas aos atos de compra e venda de imóveis, divididos pelos diferentes tipos, ocorridos na cidade no período em questão. Os tipos contidos na base de dados são: apartamento, casa, barracão, loja, sala e terreno. O estoque imobiliário foi fornecido pela Secretaria Municipal de Fazenda com base nos dados do Imposto Predial e Territorial Urbano (IPTU) para os anos 1996 e 2000.

Para entender as modificações que ocorreram na estruturação do espaço urbano de Belo Horizonte, é preciso traduzir em alguns indicadores, aplicados à nossa base de dados, as propostas teóricas contidas na seção 1, "O modelo teórico". Dividimos nossa base de dados em dois grupos, o mercado primário urbano e o mercado secundário urbano.

O mercado primário urbano é composto pelo conjunto de edificações acrescidas ao estoque urbano, em um ano, assim como pelas decisões de se construir novas edificações. Os indicadores utilizados para medir a dinâmica do mercado primário de imóveis são: o fluxo imobiliário, que representa o número de baixas em um ano, e o indicador de expectativas, representado pelo número de projetos por ano. Ao desagregarmos esses indicadores por região da cidade, obtemos aquelas em que a atividade imobiliária foi mais atuante.

O mercado secundário urbano é composto pelo conjunto de transações de compra e venda de imóveis durante um ano. Embora em cada cidade existam regiões tradicionais, cuja alta liquidez do bem imóvel o torna um ativo com pouco risco, verificamos que as regiões que estão passando por mudanças no seu padrão tendem a ter um aumento na participação nas transações. $\mathrm{O}$ indicador utilizado nesse mercado é o coeficiente de especialização no tempo (Q), que indica a tendência de mudança no padrão de ocupação da região. O indicador $(Q)$ é representado pela equação:

$$
Q=\frac{\frac{W_{i r t}}{W_{i r T}}}{\frac{W_{i R t}}{W_{i R T}}}
$$

onde $W$ é o número de transações; $i$ é o tipo de imóvel; $r$ a região da cidade; $t$ o ano; $R$ toda a cidade; e $T$ todo o período em questão. O coeficiente de especialização no tempo acima da unidade indica que a região está ganhando posição relativa no mercado do imóvel $i$; ou seja, a atividade imobiliária está alterando o seu padrão de 
8 Cada regional é subdividida em Áreas de Planejamentos (APs) que são áreas contínuas geograficamente, englobando um conjunto de bairros.

O município de Belo Horizonte possui $62 \mathrm{APs}$ e cerca de 270 bairros. ocupação. Nesse caso, na região está sendo possível extrair os ganhos ampliados da atividade imobiliária. Um indicador abaixo da unidade revela que a região está estabilizada quanto à dinâmica imobiliária.

Para indicar que tipo de ocupação está predominando em cada região da cidade, utilizamos os indicadores de densidade vertical e densidade horizontal. A densidade vertical $(V)$ é a razão entre o estoque de apartamentos da região e a área ocupada da região. A densidade horizonte $(H)$ é a razão entre o número de casas de uma região e a área ocupada da região.

A variação no tempo da densidade vertical $(\Delta V)$, maior que a variação da densidade horizontal $(\Delta H)$, indica que a região está passando por uma ocupação vertical; e, no caso contrário, a região está passando por uma ocupação horizontal. A análise do mercado secundário concentrar-se-á nas transações com apartamentos e imóveis comerciais (salas e lojas), dado que esses imóveis, em geral, são produzidos visando ao mercado, ao contrário das casas e barracos, cuja lógica de produção é marcada pela autoconstrução.

\section{1_Divisão espacial utilizada}

A Prefeitura Municipal de Belo Horizonte $(\mathrm{PBH})$ divide a cidade em nove regionais: ${ }^{8}$ Barreiro, Centro-Sul, Leste, Nordeste, Noroeste, Norte, Oeste, Pampulha e
Venda Nova. A divisão espacial que utilizaremos difere da proposta pela $\mathrm{PBH}$ por separar a regional Centro-Sul em duas regiões distintas: Centro e Sul (Figura 1 do Anexo). Essa divisão se justifica pelas diferenças internas das duas regiões. A região Centro, que corresponde a área interna aos limites da Av. Contorno, é onde se concentra a maior parte dos estabelecimentos de comércio e serviços da cidade (Tabela 1). Localizam-se na região Centro 27,3\% dos estabelecimentos de comércio do município, $34,2 \%$ dos estabelecimentos de serviços e apenas 3,1\% da população. Na região Centro estão localizados 3.093 estabelecimentos de comércio por 10.000 habitantes, contra uma proporção de 352 para o município de Belo Horizonte e 6.463 estabelecimentos de serviços por 10.000 habitantes, enquanto que, para o total do município, esse indicador é de 588. Além de ser a principal aglomeração de atividades de comércio e serviços do município, a região Centro é o destino de cerca de $1 / 3$ das viagens realizadas por moradores da região metropolitana (Costa, Silva e Veríssimo, 2004). É de se esperar, portanto, que a dinâmica imobiliária da região Centro seja diferente da das demais regiões da cidade, inclusive da região Sul, notadamente para imóveis comerciais. 
Tabela 1_Concentração de estabelecimentos de comércio e serviços na cidade de Belo Horizonte

\begin{tabular}{|c|c|c|c|c|c|}
\hline \multirow[b]{2}{*}{ Região } & \multicolumn{2}{|c|}{ Comércio } & \multicolumn{2}{|c|}{ Serviços } & \multirow{2}{*}{$\begin{array}{c}\text { População } \\
\text { \% no total } \\
\text { de população } \\
\text { da cidade }\end{array}$} \\
\hline & $\begin{array}{l}\text { Estabelecimentos/ } \\
10.000 \text { habitantes }\end{array}$ & $\begin{array}{c}\% \text { total de } \\
\text { estabelecimentos } \\
\text { da cidade }\end{array}$ & $\begin{array}{l}\text { Estabelecimentos/ } \\
10.000 \text { habitantes }\end{array}$ & $\begin{array}{c}\% \text { total de } \\
\text { estabelecimentos } \\
\text { da cidade }\end{array}$ & \\
\hline Barreiro & 170 & 5,8 & 176 & 3,6 & 12,0 \\
\hline Centro $^{(1)}$ & 3093 & 27,3 & 6463 & 34,2 & 3,1 \\
\hline Leste & 329 & 12,5 & 576 & 12,3 & 13,4 \\
\hline Nordeste(2) & 280 & 9,0 & 377 & 7,5 & 11,3 \\
\hline Noroeste & 349 & 15,0 & 470 & 12,0 & 15,1 \\
\hline Norte & 152 & 3,9 & 155 & 2,3 & 9,1 \\
\hline Oeste & 290 & 9,7 & 512 & 10,9 & 11,7 \\
\hline Pampulha & 318 & 5,3 & 549 & 5,5 & 5,9 \\
\hline Sul & 288 & 6,8 & 603 & 8,5 & 8,3 \\
\hline Venda Nova & 165 & 4,6 & 181 & 3,1 & 9,9 \\
\hline Belo Horizonte & 352 & 100,0 & 588 & 100,0 & 100,0 \\
\hline
\end{tabular}

(1) Os bairros Floresta e Santa Efigênia foram classificados totalmente na região Leste, embora parte desses bairros se localize na região Centro.

(2) O bairro Lagoinha foi classificado inteiramente na região Nordeste, embora parte desse bairro se localize na região Noroeste.

Fonte: Elaboração própria a partir de dados da PBH/PRODABEL, 2000 e Censo Demográfico, IBGE, 2000.

\section{3_Resultados}

\section{1_A estruturação do espaço intra- urbano de Belo Horizonte: histórico}

Planejada para ser a capital de Minas Gerais, a cidade de Belo Horizonte foi traçada por Aarão Reis em um plano que previa uma zona urbana - detalhada no plano -, uma zona suburbana e outra rural, estas duas últimas sem detalhamento. Atualmen- te, a região Centro corresponde à área contida no plano original. Muito tem sido escrito sobre o caráter higienista, elitista e excludente do plano (Ver Costa, 1994; Julião, 1996; Silva, 1991 e Monte-Mór, 1994). Nossa análise histórica haverá de se concentrar em como se constituiu a estruturação do espaço ur bano de Belo Horizonte, como proposto por Villaça (1998). 
$\cdots \cdots \cdots$

9 O modelo de estruturação

do espaço urbano, seguindo

um setor de círculo da

metrópole, é inspirado

em Hoyt.
Villaça (1998) identifica a estruturação do espaço intra-urbano belo-horizontino de maneira análoga à das outras metrópoles brasileiras, enquadrando a cidade, mais precisamente, no padrão metrópole do interior. Segundo essa tipologia, o espaço urbano se desenvolve a partir de uma ferrovia que corta um vale pelo qual passa um rio. A ferrovia normalmente acompanha o rio, que é uma barreira natural que divide o espaço urbano em dois. Os centros da metrópole do interior nascem, normalmente, em um dos lados do rio, criando uma divisão qualitativa no espaço urbano. Essa diferença se traduz na acessibilidade ao Centro, e a composição social do espaço urbano se origina na "luta" pela localização no "lado de cá" da barreira. Isso dá origem a uma estruturação urbana na qual os bairros de famílias abastadas se localizam em um único setor do espaço metropolitano.

Em Belo Horizonte, o rio é o Ribeirão Arrudas, que corta o espaço da cidade no sentido leste-oeste acompanhado pela ferrovia. O plano original de Aarão Reis situava-se em quase sua totalidade nas margens sul do Ribeirão, tornando essa região "o lado de cá" da cidade.

[...] [Aarão Reis] sabia que, se esse ribeirão viesse a seccionar a cidade ao meio, estaria sendo criada uma área planejada que tinha um lado melhor e outro pior, o que seria insustentável: a área planejada destinada às burguesias, tinha que ser boa integralmente. As camadas populares foram alojadas fora da área planejada (Villaça, 1998, p. 120).

A região ao sul do Arrudas foi ocupada por bairros de famílias abastadas, que fizeram dessa região seu setor de expansão. A região ao norte da área planejada se fixou como local de moradia das classes populares; e a região ao oeste da área planejada, dos operários. No início dos anos 1940, o então prefeito de Belo Horizonte, Juscelino Kubitschek, criou na zona Norte da cidade o complexo arquitetônico, paisagístico e de lazer da Pampulha, constituído de uma represa, prédios modernistas (Iate Clube, Cassino e igreja), cuja arquitetura de Oscar Niemeyer, aliada aos azulejos e pinturas de Cândido Portinari e aos jardins de Burle Marx, fez desse empreendimento o principal símbolo artístico e arquitetônico da cidade. A arquitetura modernista da Pampulha se tornou um marco tanto no cenário cultural nacional quanto mundial, como descreve Cavalcanti:

\footnotetext{
A Pampulha antecipou-se em três décadas ao sentimento de esgotamento do racionalismo funcionalista, apontando rumos alternativos à burocracia estética que rondava o modernismo dos anos quarenta (Cavalcanti, 1999, p. 385).
} 
Segundo Villaça (1998), a Pampulha não foi capaz de reverter o caminho de expansão dos bairros habitados por famílias abastadas. Embora tenha valorizado simbolicamente a região e atraído algumas famílias ricas, habitando em grandes residências unifamiliares, a região Sul continuou sendo o setor de aglomeração dos locais de moradia, consumo e trabalho das elites. Por ser distante do Centro e no lado oposto ao setor de bairros nobres, a Pampulha sempre foi considerada fora de mão. E, como conclui Villaça, localizar-se distante das regiões Centro e Sul, em Belo Horizonte, significa estar longe 'de tudo', ficar 'fora de mão'. Abandonar a direşão radial significa piorar a acessibilidade (Villaça, 1998, p. 203).

À atividade imobiliária coube fazer com que essa estrutura urbana se materializasse. Concentrar as atividades imobiliárias destinada à população de estratos de renda alto e médio em apenas um setor do círculo metropolitano, sob uma perspectiva heterodoxa, significa um comportamento avesso ao risco dos empreendedores urbanos. Sujeitos à incerteza urbana e buscando o mark up derivado das externalidades de vizinhança, os empreendedores exploraram a região Sul, dotando-a de um estoque predial que atendesse às necessidades das familias abastadas. $\mathrm{O}$ duplo movimento de inovação urbana e depreciação fictícia foi expe- rimentado durante várias décadas nos bairros das regiões Centro e Sul. As marcas dessa dinâmica são atestadas pelos dados do estoque imobiliário - em 1996 as duas regiões conjuntamente abrigavam $40,75 \%$ do estoque de apartamentos da cidade. Alguns bairros das regiões Leste e Oeste, em razão da proximidade com as regiões Centro e Sul, também tiveram um surto de verticalização. Na década de 1970, a criação do túnel da Av. Cristiano Machado tornou parte da região Nordeste atrativa à atividade imobiliária, surgindo o Bairro Cidade Nova. Nessa época, a região Sul já não era suficiente para abrigar parte da classe média, surgida pelo milagre econômico e beneficiada por uma política consistente de financiamento habitacional, mas que não tinha como arcar com os preços altos dos apartamentos nessa região.

A configuração recente do espaço intra-urbano belo-horizontino pode ser descrita utilizando a classificação proposta pelo IPEAD (Fundação Instituto de Pesquisas Econômicas, Administrativas e Contábeis de Minas Gerais), que divide os bairros de Belo Horizonte em quatro categorias luxo, alto, médio, baixo - de acordo com a renda média mensal dos chefes dos domicílios (Quadro 1). 
10 . . . . . . . . . . 10 Junto a bairros de padrão luxo e alto da região Oeste, existe um grande aglomerado de vilas e favelas denominado Morro das Pedras.

Quadro 1 Classificação dos bairros de Belo Horizonte pelo IPEAD

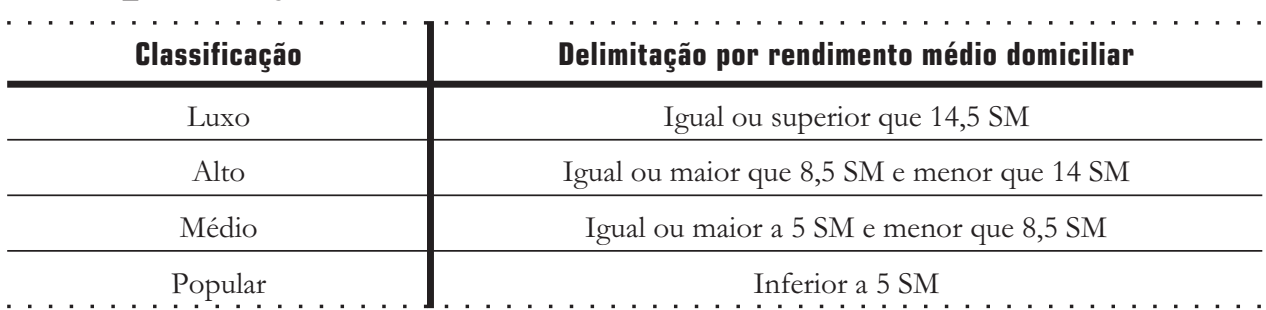

$\mathrm{SM}=$ Salário mínimo

Fonte: Dados provenientes do Censo 2000 IBGE.

As regiões Centro e Sul representam o setor onde se localizam os bairros da elite, sendo que $75,1 \%$ da população da região Sul residem em bairros de luxo, percentual que é de 64,8\% para a região Centro, conforme Tabela 2. O restante da população da região Sul reside em conglomerados de vilas e favelas $(24,9 \%)$, enquanto que o restante da população da região Centro $(35,2 \%)$ reside em bairros de padrão alto. $\mathrm{O}$ comércio e serviços de luxo estão tendendo a abandonar o Centro tradicional (bairro Centro) concentrando-se no Bairro Savassi (região Centro contíguo à região $\mathrm{Sul}$ ) e shopping centers. Nos municípios ao sul da Região Metropolitana, condomínios de luxo passaram a abrigar uma parcela das elites, em um primeiro momento como segunda residência, sendo que atualmente esses estão passando a ser a moradia definitiva de parte dessa elite.

Pampulha e Oeste são regiões que se caracterizam pela heterogeneidade da popu- lação residente, existindo nessas regiões bairros dos quatro tipos (Tabela 2). A Pampulha foi idealizada como local de moradia unifamiliar para elite, surgindo bairros de estratos de rendimento médios da população ao redor dos bairros habitados pela elite, sendo que, em 2000, 9,7\% da população da Pampulha habitava em bairros de padrão luxo, e 50,8\% em bairros de padrão alto. Os bairros de população pobre da Pampulha se localizam na divisa dessa região com o município de Contagem. Já a região Oeste se caracteriza por conter bairros de padrão luxo e alto $(21,2 \%$ da população da região) nas localizações contíguas às regiões Centro e Sul, cuja ocupação é similar à que se verifica nestas últimas. Todavia, a maior parte da população da região $(63,7 \%)$ habita em bairros classificados como baixo, sendo que esses geralmente se localizam distantes da região Centro e Sul, próximos à região do Barreiro. ${ }^{10}$ 
Tabela 2_População das regióes por classe de renda dos bairros

\begin{tabular}{c|c|c|c|c}
\multirow{2}{*}{ Região } & \multicolumn{3}{c}{$\% \ldots$ da população habitando em bairros segundo classe de renda } \\
\cline { 2 - 4 } & Luxo & \multicolumn{2}{c}{ Alto } & \multicolumn{2}{c}{ Médio } & Baixo \\
\hline Barreiro & 0,0 & 0,0 & 4,5 & 95,5 \\
\hline Centro(1) & 64,8 & 35,2 & 0,0 & 0,0 \\
\hline Leste & 0,0 & 14,9 & 39,4 & 45,7 \\
\hline Nordeste(2) & 0,0 & 8,3 & 15,8 & 76,0 \\
\hline Noroeste & 0,0 & 2,8 & 40,1 & 57,1 \\
\hline Norte & 0,0 & 0,0 & 9,5 & 90,5 \\
\hline Oeste & 6,5 & 14,6 & 15,2 & 63,7 \\
\hline Pampulha(3) & 9,7 & 50,2 & 7,1 & 33,1 \\
\hline Sul & 75,1 & 0,0 & 0,0 & 24,9 \\
\hline Venda Nova & $\ldots, 0$ & $\ldots, 0$ & $\ldots, 7 \ldots 1,3$
\end{tabular}

(1) Não incluído na região Centro as parcelas dos bairros Floresta e Santa Efigênia.

(2) Bairro da Lagoinha foi incluído totalmente na região Nordeste.

(3) Bairro Jardim Atlântico está classificado parte como luxo e parte como alto pelo Ipead.

Atribuiu-se $50 \%$ da população para cada estrato.

Fonte: Elaboração própria a partir de dados do IPEAD e Censo Demográfico 2000, IBGE.

As regiões Nordeste, Noroeste e Leste se caracterizam por conter uma pequena parte da população em bairros de padrão alto, em geral, contíguos à região Centro, e um grande número de bairros de padrões médio e baixo localizados mais distantes do Centro. A região Nordeste se caracteriza por conter maior população em bairros de padrão baixo $(76,0 \%)$, enquanto que na região Leste a proporção da população vivendo em bairros de padrão baixo é menor (45,7\%).
Barreiro, Venda Nova e Norte são as regiões mais distantes e de população mais pobre da cidade. A ocupação dessas regiões é predominantemente unifamiliar, sendo que Barreiro e Venda Nova são importantes centros de comércio popular, cuja ocupação se deu junto à construção da capital mineira, enquanto que Norte é uma região de ocupação mais recente. 


\subsection{A dinâmica imobiliária recente: 1994-2003}

3.2.1_ Dinâmica populacional, domiciliar e socioeconômica das regióes

A utilização do solo na cidade de Belo Horizonte, ao longo da década de 1990, apresentou mudanças significativas. $\mathrm{O}$ setor Sul da cidade, principal local de atuação da atividade imobiliária produtora de apartamentos no passado, vem dando sinais de exaustão. A região Nordeste, que despontou a partir dos anos 1970 como vetor alternativo, também tem apresentado queda na sua participação. A Tabela 3 mostra a ta- xa de crescimento dos domicílios particulares permanentes por região, entre 1996 e 2000, e da população, entre 1991 e 2000. A região da Pampulha foi a que apresentou maior crescimento populacional e domiciliar, indicando que a atividade imobiliária foi intensa. As regiões Norte, Venda Nova e Barreiro também manifestaram grandes taxas de crescimento para ambas as variáveis, bem como as regiões Nordeste e Oeste com taxas acima da média do município. As demais regiões exibiram crescimento populacional e domiciliar abaixo da média da cidade, evidenciando uma estabilização.

Tabela 3_ Crescimento domiciliar e populacional de Belo Horizonte

\begin{tabular}{|c|c|c|}
\hline \multirow{2}{*}{ Região } & \multicolumn{2}{|c|}{ Така de crescimento (\%) } \\
\hline & Dom. Par. Perm. (1996-2000) & População (1991-2000) \\
\hline Barreiro & 19,74 & 18,61 \\
\hline Oeste & 14,77 & 17,27 \\
\hline Sul & 9,69 & 5,64 \\
\hline Centro & 10,19 & $-2,08$ \\
\hline Leste & 8,99 & 3,71 \\
\hline Nordeste & 15,83 & 7,92 \\
\hline Noroeste & 5,34 & $-0,04$ \\
\hline Pampulha & 28,88 & 35,48 \\
\hline Venda Nova & 20,48 & 23,03 \\
\hline Norte & 17,01 & 25,80 \\
\hline
\end{tabular}

Fonte: Elaboração própria a partir de dados dos Censos 1991 e 2000, IBGE; Contagem populacional 1996, IBGE. 
A mudança ocorrida na composição social das regiões (Tabela 4) sugere que a região Oeste sofreu um processo de elitização, com a renda média do chefe de família aumentando $22 \%$ em termos reais. A Pampulha manteve estável o perfil social de seus moradores e sua posição na hierarquia socio-espacial da cidade como terceira região de maior renda familiar, ficando atrás das regiões Centro e Sul. Por outro lado, as regiões Nordeste e Barreiro apresentaram uma queda na renda média do chefe de família. A combinação de aumento da população e aumento do rendimento médio do chefe de família sugere que as regiões Oeste e Pampulha foram locais de atuação da atividade imobiliária produtora de apartamentos para familias de estratos médios de rendimento. Concentraremos nossa análise seguinte no deslocamento espacial recente dessa atividade.

\subsection{2_ Dinâmica do mercado primário}

Os indicadores do mercado primário sinalizam tanto as mudanças que estão experimentando cada região em termos do seu ambiente construído residencial quanto as expectativas de mudanças futuras nesse ambiente. Temos que o fluxo imobiliário durante todo o período se concentrou na Pampulha, tendo a região participado em quase um terço de toda a produção imobiliária da cidade (Tabela 5 ,
Figura 2 no Anexo). A região Oeste, no primeiro ano do período, era a quarta em termos de produção imobiliária e terminou o período como segunda. Já as regiões Sul e Nordeste, segunda e terceira, respectivamente, em 1994, perderam posição, indicando que a atividade imobiliária, entendida como a atuação em bloco dos empreendedores urbanos, tem deixado essas regiões.

O indicador de expectativas (Tabela 6) aponta para uma tendência a intensificação do uso do solo na região da Pampulha, que, durante todo o período, liderou o número de projetos aprovados. Em 2003, a região deteve mais de um quarto de todos os projetos na cidade, sendo que, em 2000 , $33,55 \%$ dos projetos imobiliários residenciais de Belo Horizonte a tinham como localização. Na região Oeste o indicador de expectativas apresentou-se mais errático, dando sinais de uma exaustão no poder da atividade imobiliária em modificar a forma de ocupação da região. A região Sul, a partir de 1996, tem mantido seu índice de expectativas entre 12 e $15 \%$ do total de projetos da cidade. Isso demonstra que a região ainda é a área de atuação dos grandes empreendedores urbanos, sendo local de extração do mark up urbano do tipo II. ${ }^{11}$

\footnotetext{
11 A maior parte da região Sul está sob influência da ZA (Zona Adensada) na qual a Prefeitura de Belo Horizonte desincentiva novas construções. Embora isso aumente os custos da atividade imobiliária na região, essa continua a ser significativa devido a grande demanda por apartamentos de luxo existentes nos bairros dessa região.
} 
Tabela 4_ Renda nas regióes de Belo Horizonte ( $R$ \$ 2000)

\begin{tabular}{|c|c|c|c|}
\hline Região & Renda 1991 & Renda 2000 & Tx. Variação (\%) \\
\hline Barreiro & 270,60 & 248,56 & $-8,14$ \\
\hline Oeste & 584,13 & 712,78 & 22,02 \\
\hline Sul & 1454,22 & 1477,87 & 1,63 \\
\hline Centro & 1549,26 & 1775,73 & 14,62 \\
\hline Leste & 445,36 & 478,98 & 7,55 \\
\hline Nordeste & 382,18 & 374,74 & $-1,95$ \\
\hline Noroeste & 448,82 & 457,41 & 1,91 \\
\hline Pampulha & 728,58 & 741,37 & 1,76 \\
\hline Venda Nova & 259,34 & 278,41 & 7,35 \\
\hline Norte & 266,04 & 303,00 & 13,89 \\
\hline Belo Horizonte & 638,85 & 684,89 & 7,21 \\
\hline
\end{tabular}

Fonte: Elaboração própria a partir de dados do Censo 1991 e 2000, IBGE.

Tabela 5_Fluxo imobiliário por Região (\% Participação)

\begin{tabular}{|c|c|c|c|c|c|c|c|c|c|c|c|}
\hline Ano & Barreiro & Deste & Sul & Centro & Leste & Nordeste & Noroeste & Pampulha & $\begin{array}{l}\text { Venda } \\
\text { Nova }\end{array}$ & Norte & $\begin{array}{c}\text { Belo } \\
\text { Horizonte }\end{array}$ \\
\hline 1994 & 2,43 & 11,35 & 15,14 & 1,08 & 5,95 & 11,89 & 8,38 & 26,49 & 14,05 & 3,24 & 100,00 \\
\hline 1995 & 1,44 & 14,00 & 14,54 & 1,44 & 7,90 & 10,05 & 12,21 & 28,90 & 7,18 & 2,34 & 100,00 \\
\hline 1996 & 2,26 & 16,38 & 14,29 & 1,57 & 8,36 & 11,50 & 10,80 & 24,91 & 6,79 & 3,14 & 100,00 \\
\hline 1997 & 2,96 & 18,72 & 12,80 & 2,96 & 6,75 & 9,24 & 9,72 & 25,00 & 8,65 & 3,20 & 100,00 \\
\hline 1998 & 2,51 & 15,71 & 10,69 & 2,83 & 7,85 & 9,15 & 10,04 & 27,94 & 9,88 & 3,40 & 100,00 \\
\hline 1999 & 1,83 & 13,84 & 12,97 & 1,52 & 4,85 & 8,19 & 8,35 & 29,59 & 9,47 & 9,39 & 100,00 \\
\hline 2000 & 2,69 & 14,41 & 13,68 & 1,24 & 6,33 & 7,86 & 9,53 & 28,46 & 8,81 & 6,99 & 100,00 \\
\hline 2001 & 3,45 & 12,82 & 11,94 & 1,44 & 6,89 & 7,37 & 11,14 & 29,81 & 7,53 & 7,61 & 100,00 \\
\hline 2002 & 3,13 & 13,59 & 12,78 & 1,57 & 8,08 & 8,99 & 9,98 & 29,18 & 8,08 & 4,62 & 100,00 \\
\hline 2003 & 3,00 & 13,13 & 10,60 & 1,51 & 7,32 & 9,38 & 8,72 & 28,89 & 9,85 & 7,60 & 100,00 \\
\hline
\end{tabular}

Fonte: Elaboração própria a partir de dados da Secretaria Municipal de Regulação Urbana (SMRU-PBH). 
Tabela 6_ Indicador de Expectativas por Região (\% total da cidade)

\begin{tabular}{|c|c|c|c|c|c|c|c|c|c|c|c|}
\hline Ano & Barreiro & Deste & Sul & Centro & Leste & Nordeste & Noroeste & Pampulha & $\begin{array}{l}\text { Venda } \\
\text { Nova }\end{array}$ & Norte & $\begin{array}{c}\text { Belo } \\
\text { Horizonte }\end{array}$ \\
\hline 1994 & 7,33 & 10,44 & 10,00 & 4,44 & 8,89 & 8,89 & 13,11 & 19,78 & 8,44 & 8,67 & 100,00 \\
\hline 1995 & 6,81 & 12,31 & 9,67 & 3,08 & 6,37 & 10,99 & 11,87 & 24,40 & 9,23 & 5,27 & 100,00 \\
\hline 1996 & 9,35 & 9,97 & 13,08 & 2,18 & 5,61 & 12,15 & 10,59 & 24,61 & 4,98 & 7,48 & 100,00 \\
\hline 1997 & 7,73 & 9,66 & 10,14 & 0,72 & 4,11 & 7,97 & 11,11 & 32,85 & 9,18 & 6,52 & 100,00 \\
\hline 1998 & 7,58 & 9,78 & 14,18 & 2,20 & 6,85 & 9,78 & 7,58 & 32,03 & 5,62 & 4,40 & 100,00 \\
\hline 1999 & 9,03 & 9,03 & 10,90 & 0,62 & 6,23 & 9,03 & 9,97 & 31,15 & 7,48 & 6,54 & 100,00 \\
\hline 2000 & 4,15 & 7,67 & 18,53 & 3,19 & 6,39 & 7,99 & 7,35 & 33,55 & 7,03 & 4,15 & 100,00 \\
\hline 2001 & 6,42 & 12,57 & 12,03 & 1,87 & 7,75 & 5,88 & 9,36 & 33,16 & 5,88 & 5,08 & 100,00 \\
\hline 2002 & 4,29 & 11,11 & 18,32 & 3,90 & 6,24 & 8,97 & 9,55 & 29,24 & 3,51 & 4,87 & 100,00 \\
\hline 2003 & 3,65 & 12,86 & $\begin{array}{r}13,94 \\
\therefore .\end{array}$ & 3,92 & 9,20 & $\begin{array}{l}7,58 \\
. .\end{array}$ & 6,77 & 27,47 & 1,89 & 12,72 & 100,00 \\
\hline
\end{tabular}

Fonte: Elaboração própria a partir de dados da Secretaria Municipal de Regulação Urbana (SMRU)-PBH.

\subsection{3_ A dinâmica do mercado secundário}

O mercado secundário de apartamentos engloba todas as transações com esse tipo de imóvel que ocorrem no mercado formal. A conjunção da análise da dinâmica do mercado primário com a dinâmica do mercado secundário permite que identifiquemos em qual fase do ciclo de vida a região se encontra. A região Sul mantevese como o maior mercado de apartamentos, embora tenha caído em 3,4 pontos percentuais no período. Embora seja uma região com reputação de líquida quanto ao estoque imobiliário, a perda do dina- mismo da atividade imobiliária na região reflete no mercado secundário (Tabela 7 , Figura 3 no Anexo). A região Oeste ganhou uma posição na escala das transações, passando a ser o segundo maior mercado para apartamentos na cidade. A Pampulha saiu de uma posição incipiente no ano de 1994, estando em 2003 como o terceiro maior mercado para negócios com apartamentos, registrando um aumento de 5,24 pontos percentuais e ultrapassando a região Centro, que, de segundo mercado em 1994, passou para a quarta posição em 2003. 
Tabela 7_ Transações com Apartamentos por Região (\% Cidade)

\begin{tabular}{|c|c|c|c|c|c|c|c|c|c|c|c|}
\hline Ano & Barreiro & Deste & Sul & Centro & Leste & Nordeste & Noroeste & Pampulha & $\begin{array}{l}\text { Venda } \\
\text { Nova }\end{array}$ & Norte & $\begin{array}{c}\text { Belo } \\
\text { Horizonte }\end{array}$ \\
\hline 1995 & 1,85 & 16,01 & 23,81 & 16,65 & 11,10 & 9,78 & 9,94 & 6,77 & 3,28 & 0,81 & 100,00 \\
\hline 1996 & 1,56 & 17,47 & 21,91 & 15,49 & 9,51 & 10,03 & 9,89 & 6,88 & 1,95 & 5,31 & 100,00 \\
\hline 1997 & 2,57 & 18,95 & 19,54 & 14,17 & 10,27 & 9,56 & 11,85 & 8,27 & 3,15 & 1,67 & 100,00 \\
\hline 1998 & 2,32 & 17,98 & 19,81 & 15,95 & 9,56 & 9,62 & 11,26 & 8,75 & 3,34 & 1,41 & 100,00 \\
\hline 1999 & 2,95 & 18,23 & 18,62 & 16,17 & 9,34 & 8,98 & 9,94 & 10,02 & 3,33 & 2,42 & 100,00 \\
\hline 2000 & 3,49 & 16,88 & 18,24 & 13,86 & 9,09 & 9,14 & 10,94 & 11,80 & 3,37 & 3,19 & 100,00 \\
\hline 2002 & 2,77 & 16,82 & 18,57 & 15,92 & 9,01 & 8,68 & 10,19 & 12,53 & 2,77 & 2,74 & 100,00 \\
\hline 2003 & 2,67 & 17,23 & 17,71 & 13,19 & 9,31 & 8,96 & 10,52 & 13,67 & 3,54 & 3,20 & 100,00 \\
\hline
\end{tabular}

Fonte: Elaboração própria a partir de dados da Prodabel/PBH - ITBI.

12 Apesar dessa realidade, grande parte da região está sob influência da ZAP (zona de adensamento preferencial) na qual a prefeitura incentiva o adensamento.
O coeficiente de especialização no tempo $(\mathrm{Q})$ indica as tendências de mudanças na ocupação do solo urbano, apontando as regiões que têm ganhado importância relativa na atuação da atividade imobiliária e aquelas que vêm perdendo. O gráfico com a evolução do indicador $(\mathrm{Q})$ no tempo revela que a região Oeste recebeu parte da atividade imobiliária que abandonou a região Sul, onde já não era mais possível extrair o mark up urbano do tipo I. A atuação maciça na região Oeste, porém, deu-se em um curto espaço de tempo (1997-2000), o que, em termos espaciais, significa que a atividade se concentrou em algumas localizações selecionadas da região (Gráfico 1). A conjunção de crescimento no fluxo imobiliário com a importância relativa das transações imobiliárias mostra que a região passou por uma alteração no seu ciclo de vida no período entre 1997 e 2000 . A queda no indicador de expectativa, combinada com a queda no coeficiente de especialização no tempo, indica uma tendência à estabilização no ciclo da região. ${ }^{12}$ 


\section{Gráfico 1_Transações com Apartamentos - Índice q - Sul e Oeste - 1994/2003 \\ - Média Móvel Trienal}

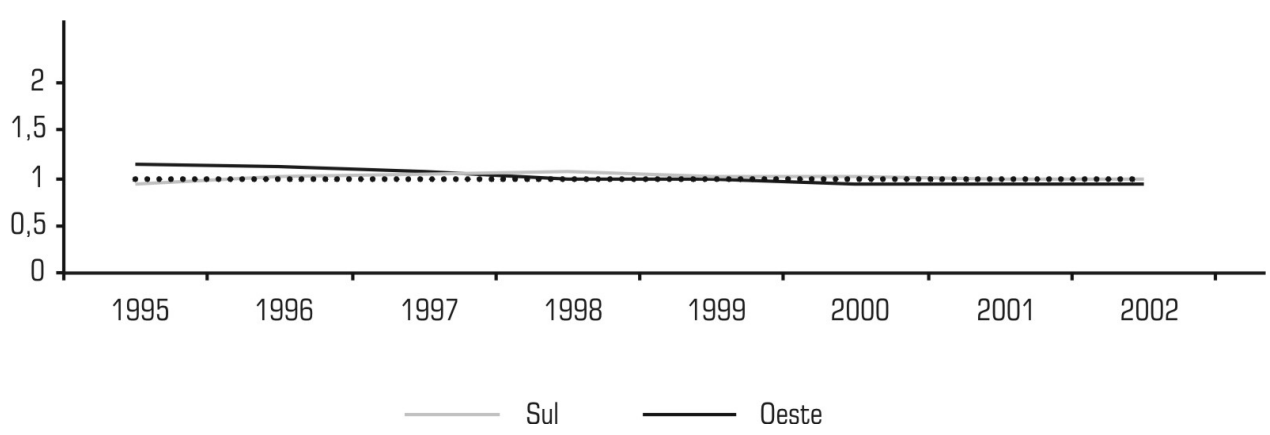

Parte da atividade imobiliária, que abandonou a região Sul, passou a atuar na região da Pampulha (Gráfico 2). A Pampulha também recebeu a atividade imobiliária que atuou na região Nordeste (Gráfico 3) e apresentou crescimento no fluxo imobiliário, combinado com um ganho de importância relativa nas transações com apartamentos, o que registra ainda uma fase de transição do seu ciclo de vida. A atividade imobiliária tem, portanto, alterado o padrão de ocupação da região. Constituída de bairros cujo padrão de edificação era predominantemente horizontal, a região vem passando por um processo de verticalização significativo (Tabela 8). O estoque de ca- sas ainda é maior que o de apartamentos, embora cresça em uma velocidade menor.

\subsection{4_ A lógica dos deslocamentos espaciais}

Identificamos na seção anterior as regiões da Pampulha e Oeste como vetores de expansão da atividade imobiliária produtora de apartamentos, apesar de a última já apresentar evidências de exaustão nesse processo. Já os indicadores para a região da Pampulha revelam a tendência da permanência da atividade imobiliária, alterando a forma de ocupação da região por algum tempo. Foram identificadas também as regiões Sul e Nordeste como "exportadoras" da atividade imobiliária. Cabe agora indagar as razões para esses deslocamentos. 
Gráfico 2_Transações com Apartamentos - Índice q - Sul e Pampulha - 1994/2003

- Média Móvel Trienal

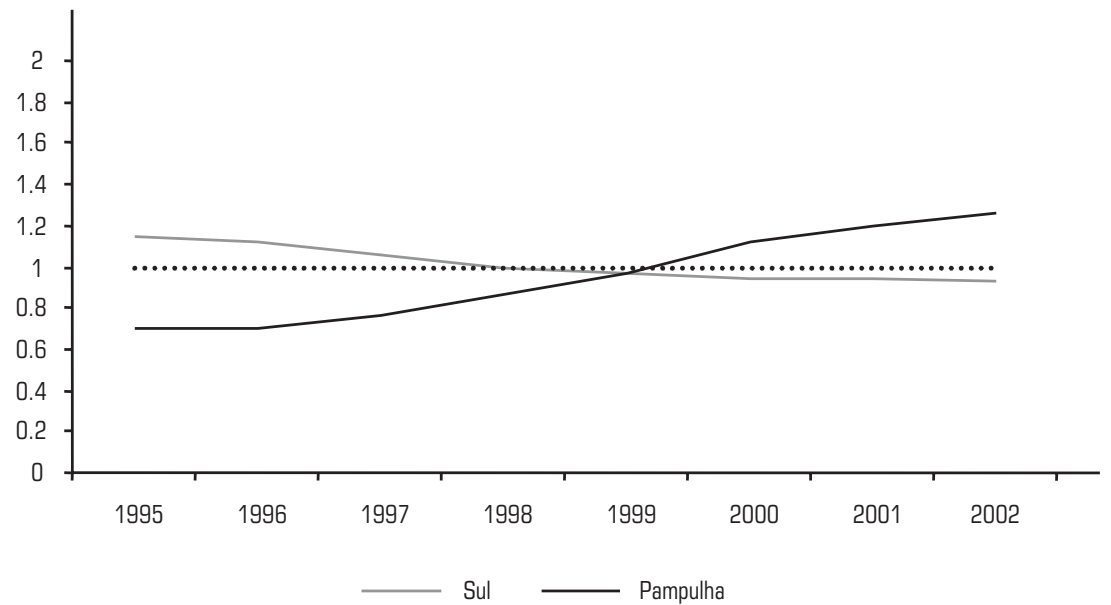

Gráfico 3_ Transações com Apartamentos - Índice q - Nordeste e Pampulha - 1994/2003 - Média Móvel Trienal

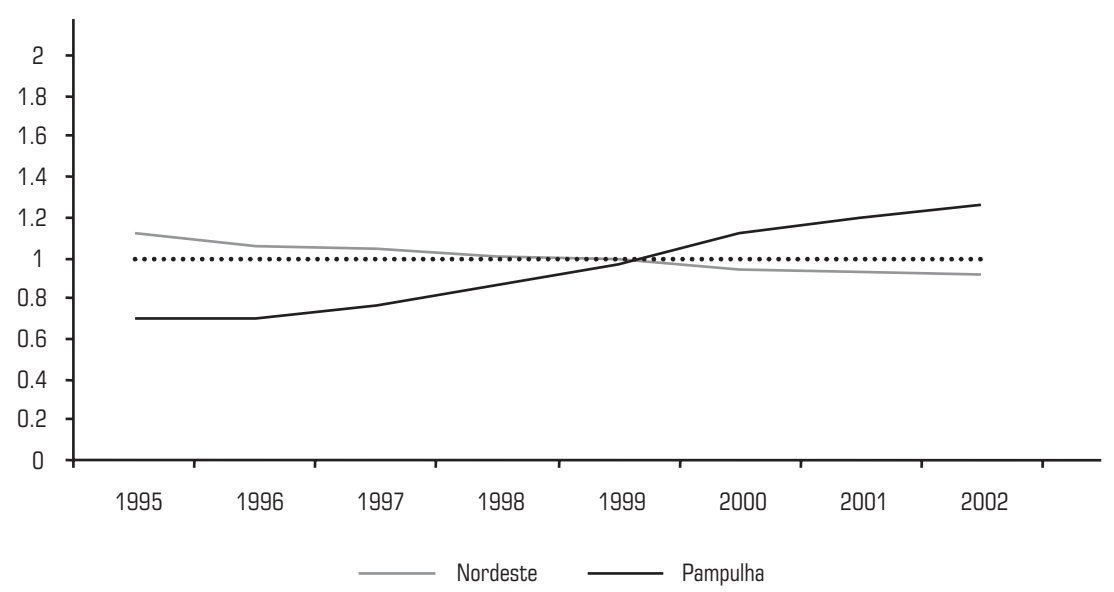


Tabela 8_Forma de ocupação do solo das regióes 1996/2000

\begin{tabular}{|c|c|c|c|}
\hline Região & $\Delta \mathbf{V}$ & $\Delta \mathbf{H}$ & Ocupação \\
\hline Centro Sul & 272,89 & $-17,04$ & Vertical \\
\hline Oeste & 209,76 & 19,37 & Vertical \\
\hline Pampulha & 100,18 & 36,43 & Vertical \\
\hline Barreiro & 12,99 & 16,46 & Horizonta \\
\hline Venda Nova & 38,09 & 87,10 & Horizonta \\
\hline Norte & 44,08 & 52,30 & Horizonta \\
\hline Leste & 95,73 & $-1,41$ & Vertical \\
\hline Nordeste & 57,72 & 34,91 & Vertical \\
\hline Noroeste & 99,37 & 19,47 & Vertical \\
\hline
\end{tabular}

Fonte: Elaboração própria a partir dos dados da Prodabel/PBH, 1996 e 2000.

A estabilização do ciclo de vida da região Sul é mensurada pela combinação de queda no fluxo imobiliário, com a perda de importância relativa nas transações com apartamento no mercado secundário. A grande ocupação da região fez com que a oferta de terrenos ficasse escassa, levando a um aumento no preço da terra. Esse fenômeno começou a ocorrer nos anos 1970, com o deslocamento de parte da atividade imobiliária, destinada a famílias de classe média com menor poder aquisitivo, para a região Nordeste. Nos anos 1990 esse fenômeno se tornou mais agudo, impondo uma barreira à atuação de pequenos e médios empreendedores que já não conseguiam arcar com os preços dos terrenos. A Lei de Ocu- pação do Solo de 1996 atuou desincentivando a ocupação da maior parte dos bairros da região e acabou por contribuir para aumentar a barreira à entrada dos pequenos e médios empreendedores. A atuação da atividade imobiliária na região Sul, e também na região Centro, tem se tornado pontual e concentrada em produtos de alto padrão. Ou seja, não é mais possível se extrair o mark up urbano do tipo I nessas regiões que passaram a ser local de atuação de empreendedores de grande porte - extraindo o mark up do tipo II.

A estabilização do ciclo de vida da região Nordeste contrasta com o aumento do seu estoque domiciliar e de sua população. A queda na renda média das famílias da re- 
$\ldots \ldots \ldots \ldots$

13 Os preços de apartamentos nas áreas de expansão da região Oeste são maiores que na Pampulha. gião, durante os anos 1990, indica que essa vem se tornando local de moradia para a população pobre. Como a atividade imobiliária produtora de apartamentos atende às famílias de extrato médio e alto de rendimento, o crescimento da população pobre foi acompanhado de uma produção imobiliária marcada pela autoconstrução. A conjunção de um grande crescimento do número de domićlios particulares permanentes com um número médio de baixas indica um "aquecimento" da produção imobiliária informal na região. Apesar de ter tido uma ocupação mais vertical (Tabela 8), a distância entre a variação da densidade vertical e horizontal foi pequena para a região.

Comparando-se com a região Sul, onde a combinação entre preço do solo urbano elevado e escassez de terrenos serviu como fator de expulsão dos pequenos e mé- dios empreendedores urbanos, na região Nordeste a concentração de bairros habitados por população pobre serviu como mecanismo de expulsão da atividade imobiliária (Tabela 9).

A região Oeste recebeu parte da atividade imobiliária que abandonou a região Sul. A ocupação da região se deu de forma abrupta em um pequeno espaço de tempo, concentrada em uma minilocalização (AP Buritis). Vizinha à região Sul, na região Oeste a atividade imobiliária foi capaz de extrair um mark up de contigüidade. ${ }^{13}$ A grande oferta de terrenos, na microlocalização da AP Buritis, fez com que o preço da terra não fosse um constrangimento, e, com o benefício da localização - a AP Buritis faz parte do setor Sul da metrópole - foi possível, durante um curto espaço de tempo para a atividade imobiliária, extrair o mark up tipo I.

Tabela 9_ Renda mensal média dos chefes de domicílios da região Nordeste

\begin{tabular}{|c|c|}
\hline AP & Renda (R\$ 2000) \\
\hline Belmonte & 247,14 \\
\hline Cachoerinha & 387,84 \\
\hline Capitão Eduardo & 158,47 \\
\hline Concórdia & 501,42 \\
\hline Cristiano Machado & 829,48 \\
\hline Ribeiro de Abreu & 213,14 \\
\hline São Paulo/Goiânia & 285,66 \\
\hline
\end{tabular}


A composição social da região se alterou bastante, tendo a renda média das famílias aumentado em 22\%, entre 1991 e 2000, o que indica que parte da população que já não conseguia arcar com os altos preços dos imóveis nas regiões Centro e Sul passou a habitar a região Oeste. Cabe questionar as razões para o rápido esgotamento do ciclo ascendente da atuação da atividade imobiliária na região.

Assim como a região Nordeste, a região Oeste é heterogênea quanto à composição social dos seus bairros. Muitos dos bairros ali são locais tradicionalmente ocupados por famílias de estratos inferiores de renda (Tabela 10) e por vilas e favelas. ${ }^{14}$ Além disso, a área apresenta o maior número de homicídios na cidade. ${ }^{15}$ Ou seja, extrair os ganhos da atividade imobiliária - dependente da estruturação espacial das externalidades de vizinhança - tornou-se difícil no conjunto da região. A conjunção da presença de bairros habitados por população pobre com altos índices de violência tornou-se uma barreira social à atuação da atividade imobiliária, seguindo as premissas do paradigma das externalidades de vizinhança. ${ }^{16}$

A Pampulha se tornou o vetor de expansão da atividade imobiliária, produtora de apartamentos, apesar de estar descolada da região Sul. Como proposto por Villaça (1998), os bairros de famílias abastadas tendem a se concentrar em um setor da metrópole, e, segundo a abordagem heterodoxa da economia urbana, a atividade imobiliária tem a propensão a se deslocar para áreas contíguas como uma estratégia para diminuir os riscos. Esse parece ter sido o caso do deslocamento da atividade da região Sul para a Oeste e da região Nordeste para a Pampulha.

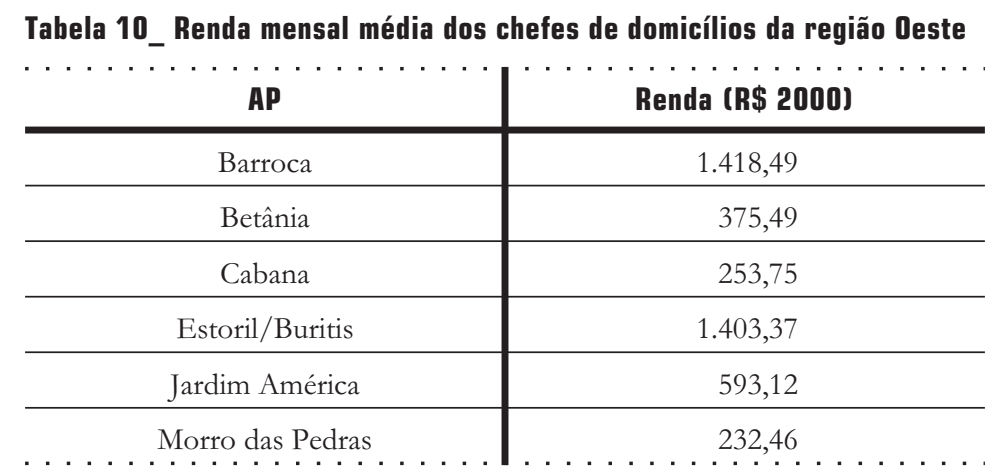

Fonte: PBH/PRODABEL, a partir de dados do Censo Demográfico 2000, IBGE. $\cdots \cdots$

14 A região Oeste concentrava, em 1993, 22,4\% dos moradores de favelas da cidade, sendo que $32,25 \%$ da população da região habitavam em favelas, segundo dados da Urbel/PBH.

15 A região Oeste apresentou 20,5\% do total de homicídios ocorridos em Belo Horizonte, no período 1995-2003, segundo dados do Centro de Estudos de Criminalidade e Segurança Pública (CRISP) da Faculdade de Filosofia e Ciências Humanas (FAFICH/UFMG).

16 O esgotamento da tendência ascendente do ciclo de vida da região Oeste explicita o papel das externalidades de vizinhança como fator de estruturação do espaço urbano. Embora a maior parte da região não estivesse sujeita a restrições construtivas, o perfil socioeconômico da população da região foi o fator preponderante para a reversão do ciclo. 
$\ldots \ldots \ldots$

17 Seria interessante um estudo da composição da demanda pelos apartamentos produzidos em massa na Pampulha. Podemos inferir que, ao contrário do previsto no projeto dos anos 1940, a região tem sido ocupada por famílias provenientes de bairros contíguos à região, não sendo uma ocupação de famílias de maior padrão de rendimento da classe média e da classe alta. Mas sim famílias dos estratos médios e baixos da classe média.

18 Segundo levantamento da Urbel/PBH, na Pampulha habitava $1,86 \%$ do total de moradores de favelas em Belo Horizonte em 1983, sendo que 6,26\% dos seus habitantes moravam em favelas.

19 A Pampulha registrou $4,11 \%$ do total de homicídios de Belo Horizonte no período 1995-2003, sendo a região da cidade menos violenta por esse critério. Dados do CRISP/FAFICH.

20 A UFMG é a maior universidade do Estado de Minas Gerais e atrai estudantes e pesquisadores de várias partes do Estado e do País.
O deslocamento, porém, da atividade imobiliária da região Sul em direção à Pampulha requer outras considerações. Tratase de uma região distante do Centro, localizada no norte geográfico da cidade, e sempre teve a acessibilidade como o principal empecilho à sua ocupação. Todavia, alguns fatores contribuíram para tornar o lugar atraente, favorecendo o conjunto da atividade imobiliária na extração do mark up urbano do tipo I. ${ }^{17}$

Primeiramente, a região foi ocupada historicamente por famílias dos extratos de renda média e alto que habitavam residências unifamiliares. $\mathrm{O}$ pequeno número de favelas $^{18}$ e o índice de violência relativamente baixo ${ }^{19}$ também contribuíram para aumentar a expectativa dos potenciais adquirentes de imóveis visando usufruir as externalida- des de vizinhança na região. A presença da Lagoa com o complexo de lazer e cultural, que inclui clubes, bares, restaurantes, parques, estádio de futebol e o campus da Universidade Federal de Minas Gerais, ${ }^{20}$ garante a valorização simbólica da região, contribuindo para a sua reputação de região rica e aprazível. A Tabela 11 apresenta o rendimento médio dos chefes de familia por Área de Ponderação (AP). Comparando os rendimentos médios das APs da região Oeste (Tabela 10), temos que a desigualdade espacial de renda é menor na Pampulha.

A renda média dos chefes de domicílio na região da Pampulha permaneceu estável entre 1991 e 2000, crescendo cerca de $2 \%$, a despeito das significativas mudanças no uso e ocupação do solo que essa região tem passado.

\section{Tabela 11_Renda mensal média dos chefes de domicílios da região Pampulha}

\begin{tabular}{|c|c|}
\hline AP & Renda (R\$ 2000) \\
\hline Castelo & 801,65 \\
\hline Jaraguá & 654,58 \\
\hline Pampulha & $1.154,49$ \\
\hline Santa Amélia & 762,22 \\
\hline Sarandi & 333,89 \\
\hline
\end{tabular}

Fonte: PBH/PRODABEL, a partir de dados do Censo Demográfico 2000, IBGE. 
As razões para esse fato podem ser duas. Primeiramente, a acessibilidade pode ser de fato um constrangimento para um deslocamento das familias mais abastadas. Nesse caso, as famílias que já não conseguiam arcar com os preços dos apartamentos nas regiões Centro e Sul, mas eram capazes de pagar um "prêmio" pela acessibilidade, acabaram por habitar a região Oeste. Por outro lado, na região da Pampulha não há a "barreira social" limitando a atuação da atividade imobiliária, como na região Oeste, por isso constatamos o aumento do leque espacial e social para a atuação dos empreendedores urbanos, que podem oferecer na região imóvel para diferentes tipos de família, incluindo famílias de classe média com menor poder aquisitivo.

\subsection{O deslocamento da atividade imobiliária comercial}

Os dados do ITBI permitem que tracemos o deslocamento espacial das transações com salas e lojas, apresentando os locais que tendem a concentrar as atividades comerciais. Até a década de 1970, esses se concentravam no centro histórico da cidade. A partir dessa década, as metrópoles brasileiras começam a passar por um fenômeno de deterioração do seu centro histórico (Villaça, 1998). Esse fenômeno consiste no abandono do centro histórico como local de moradia, consumo e trabalho das famílias abastadas. No primeiro momento, as elites deixaram de ter o centro histórico como seu local de moradia e atualmente esse processo tem se traduzido no deslocamento dos locais de consumo e trabalho das elites para outras localizações. ${ }^{21}$ Ao mesmo tempo em que as famílias abastadas vão deixando de freqüentar o centro histórico da cidade, esse passa a ser ocupado predominantemente pelas famílias mais pobres, sendo o fenômeno de deterioração do Centro correlato ao de popularização. Do ponto de vista da economia heterodoxa, isso pode ser lido como uma manifestação da depreciação fictícia, dado que o que causou a depreciação do ambiente construído do Centro foi a depreciação prévia dos tipos sociais que freqüentam ou residem na região.

Em Belo Horizonte, a criação de um centro de comércio e serviços de luxo na Savassi, na década de 1970, marcou o início da expansão das atividades comerciais em direção à região Sul. Na década de 1990, esse processo apresenta sinais de expansão, como pode ser visto pela análise da evolução do coeficiente de especialização no tempo (Gráficos 4 e 5). $\therefore \cdots$

21 Segundo Villaça (1998), a forma de estruturação do espaço urbano com a localização dos bairros de elite em um único setor da cidade não causa uma simbiose do Centro com o restante da cidade, como acontece quando esses bairros formam um círculo em torno do Centro. A ênfase dada ao automóvel particular na estruturação do sistema viário das cidades brasileiras tornou viável uma distribuição dos locais de trabalho e consumo mais dispersa no espaço. 
Gráfico 4_Transações com Lojas - Índice q - Centro e Sul - 1994/2003

- Média Móvel Trienal

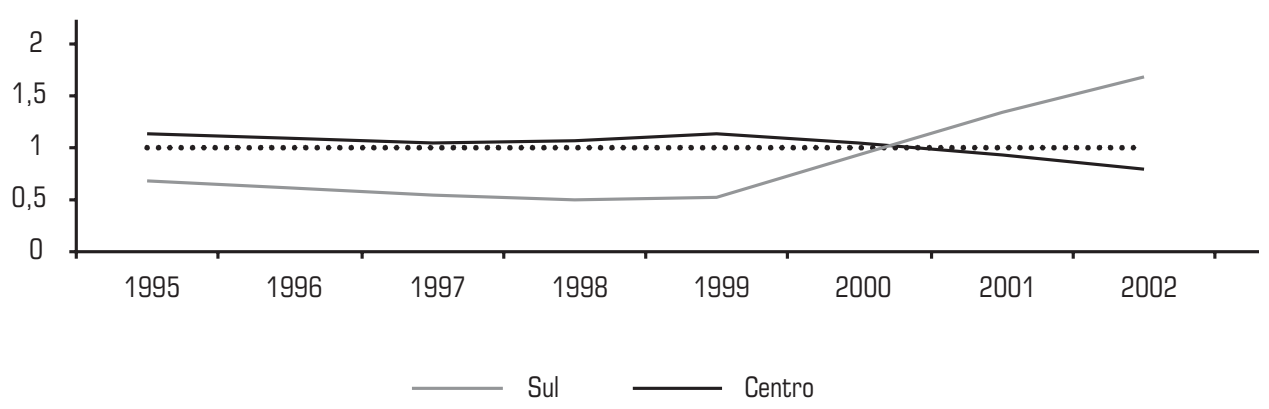

Gráfico 5_Transações com Salas - Índice q - Centro, Sul e Oeste - 1994/2003

- Média Móvel Trienal

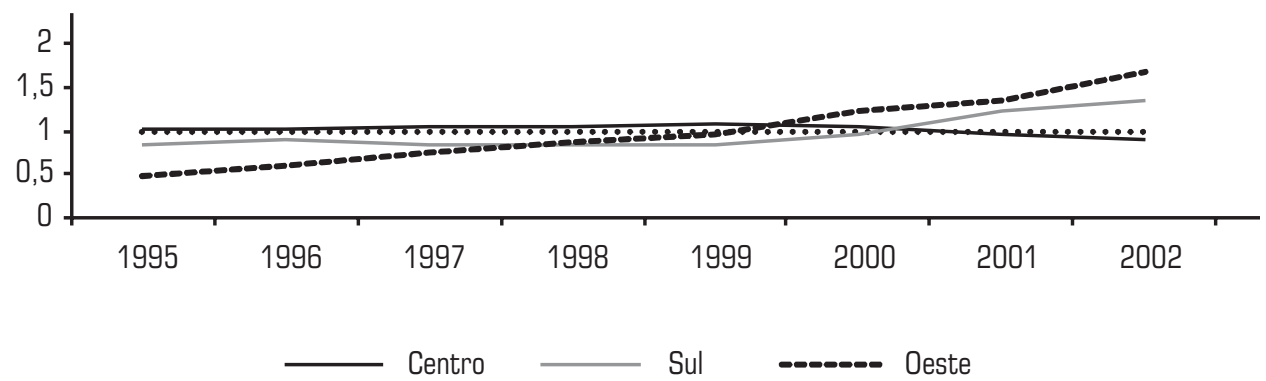


A curva do coeficiente $(\mathrm{Q})$ para as transações com lojas indica que essas tendem a se concentrar na região Sul. Já o coeficiente para as salas indica que tanto a região Sul como a Oeste são propensas a concentrar os serviços de alto padrão que têm deixado a região Centro. As lojas e as salas de alto padrão são locais de consumo e trabalho para as familias abastadas, que tendem a ter como local de moradia o setor Sul da metrópole (sul da região Centro, região Sul, parte da região Oeste e os condomínios fechados localizados nos municípios vizinhos). Ao se deslocar as salas e as lojas para o Sul, elas se tornam ainda mais acessíveis para as famílias abastadas e menos acessíveis para a população pobre, que tende cada vez mais a ter a região Sul como local de trabalho.

\section{4_Conclusão}

Este artigo analisou a estruturação do espaço intra-urbano belo-horizontino, tendo como referência a economia urbana heterodoxa. Partimos da proposta metodológica keynesiana e aplicamos o conceito de convenção como guia de ação das famílias ao escolherem sua localização no espaço urbano, em um contexto marcado pela incerteza urbana. $\mathrm{O}$ espaço urbano é estruturado a partir do desejo das famílias de usufruírem externalida- des de vizinhança, tendo nas características socioeconômicas dos moradores de uma localização o parâmetro norteador de sua escolha. Os empreendedores urbanos oferecem as moradias às famílias $\mathrm{e}$ tentam controlar esse mercado por meio da inovação espacial. Essa coordenação, porém, dá-se no nível cognitivo, sendo sujeita a falhas e mudanças repentinas.

Na seção 2, "Bases de dados e metodologia", construímos uma série de indicadores que permitem aplicar os preceitos teóricos keynesianos à base de dados sobre a atividade imobiliária. Valendo-nos dos indicadores de fluxo imobiliário, expectativas e coeficiente de especialização no tempo, detectamos um deslocamento espacial da atividade imobiliária produtora de apartamentos, que tende a abandonar as regiões Nordeste e Sul e a se concentrar na região da Pampulha, embora tenha atuado de maneira significativa na região Oeste. Identificamos que as forças que "expulsaram" a atividade imobiliária da região Nordeste foram as mesmas que limitaram sua penetração na região Oeste, isto é, a presença de bairros de população pobre, vilas e favelas ocupando parte dessas regiões. Já a atividade imobiliária que restou na região Sul atua de forma pontual, construindo prédios de luxo e obtendo o mark up urbano tipo II por meio da diferenciação do produto. A Pampulha foi o 
vetor de expansão da atividade imobiliária residencial, uma vez que reuniu uma série de fatores positivos - que constituem as externalidades de vizinhança -, como ter sido habitada tradicionalmente por famílias de classe média e alta e ter sido valorizada simbolicamente pela presença do complexo arquitetônico em torno da Lagoa. A atividade comercial tende a se concentrar na região Sul, corroborando a tese de que o centro histórico da cidade está sofrendo um processo de deterioração. $\mathrm{O}$ deslocamento da atividade comercial para a região Sul a torna mais acessível à elite que habita nessa mesma região, tornando-a menos acessível à população de classe baixa.

O estudo da estruturação urbana por uma ótica econômica é capaz de trazer algumas contribuições à prática do planejamento urbano. Entender a cidade como uma entidade econômica requer estudos da dinâmica imobiliária, reveladora das ações dos atores quanto à localização no espaço urbano. Identificados os vetores de expansão da cidade, cabe ao formulador das políticas urbanas tentar agir ante a realidade que the é imposta pela ação dos indivíduos no mercado imobiliário. E pensar o sistema de transporte, a localização de bens públicos, de equipamentos culturais e de lazer, etc. requer o conhecimento da dinâmica das localizações intra-urbanas. 


\section{Referências bibliográficas}

ABRAMO, Pedro. A convenção urbana: a dinâmica cognitiva da coordenação espacial pelo mercado. In: ENCONTRO NACIONAL DA ANPUR, 6 , 1995, Brasília. Anais... Brasília: Associação Nacional de Pós-Graduação e Pesquisa em Planejamento Urbano e Regional, 1995a.

ANDRADE, Rogério. A agenda do keynesianismo filosófico: origens e perspectivas. Revista de Economia Politica, v. 2, n. 78,2000 .

ANDRADE, Rogério. Convention as the condition for social-economic behaviour. Instituto de Economia: UNICAMP, 2003. (mimeo).

CAVALCANTI, Lauro. Quando o Brasil era moderno. Rio de Janeiro: Aeroplano, 1999.

COSTA, Marco; SILVA, Jane; VERÍSSIMO, José. Avaliacão do sistema de transporte coletivo de Belo Horizonte, 1993-2003. 2003.

Disponível em: $<$ http://www. cedeplar. ufmg.br/pesquisa $>$. Acesso em: 7 jan. 2004.

COSTA, Heloísa. Habitação e produção do espaço em Belo Horizonte. In: MONTE-MÓR, Roberto (Org.). Belo Horizonte: espacos e tempos em construcão. Belo Horizonte: PBH/ CEDEPLAR/UFMG, 1994.
DAVIS, John (Org.). Keyne's philosophical thinking. In: DAVIS, John. The state of interpretation of Keynes. Boston/ London: Kluwer Academic, 1994.

GALVÃO, Olímpio. Externalidades e desenvolvimento urbano: reflexões a partir do estatuto da cidade. Revista Brasileira de Estudos Urbanos e Regionais, v. 7, n. 2, 2005.

JULIÃO, Letícia. Itinerários da cidade moderna (1891-1920). In: DUTRA, Eliana. BH: horizontes históricos. Belo Horizonte: C/Arte, 1996.

KEYNES, John. A teoria geral do emprego. In: SZMRECSÁNYI, Tamás (Org.). Keynes. São Paulo: Ática, 1984.

MONTE-MÓR, Roberto (Org.). A cidade planejada e a metrópole em construção. In: MONTE-MÓR, Roberto. Belo Horizonte: espaços e tempos em construção. Belo Horizonte: PBH/CEDEPLAR/

UFMG, 1994

\section{SCHUMPETER, Joseph.}

Teoria do desenvolvimento econômico: uma investigação sobre lucros, capital, crédito, juro e o ciclo econômico. São Paulo: Nova Cultural, 1982.
SILVA, Regina. A cidade de minas. 1991. Dissertação (Mestrado em Ciências Políticas) - Universidade Federal de Minas Gerais, Belo Horizonte, DCP/FAFICH/ UFMG, 1991.

VILLAÇA, Flávio. Espaço intra-urbano no Brasil. São Paulo: Nobel/FAPESP, 1998.

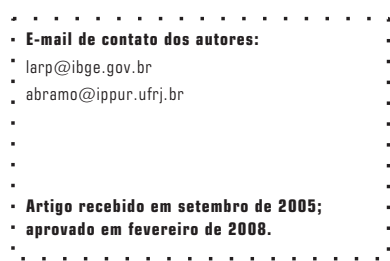


Anexo

\section{Figura 1_ Regiões de Belo Horizonte e principais vias}

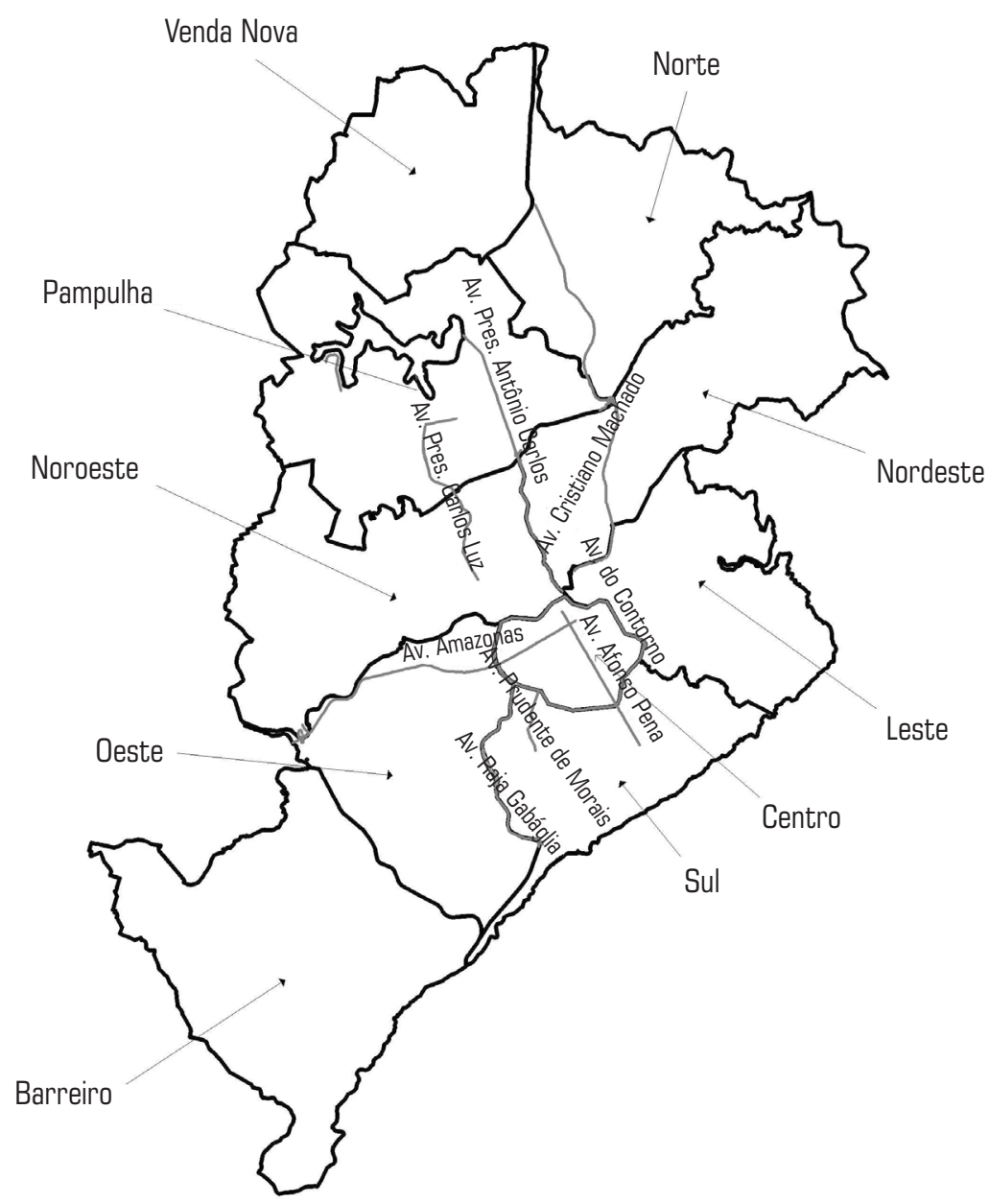

Fonte: Centro de Estudos de Criminalidade e Segurança Pública da Faculdade de Filosofia e Ciências Humanas da UFMG (CRISP/FAFICH/UFMG). Elaborado por Bráulio Figueiredo Alves da Silva. 
Figura 2_Fluxo Imobiliário de Belo Horizonte 1994-2003

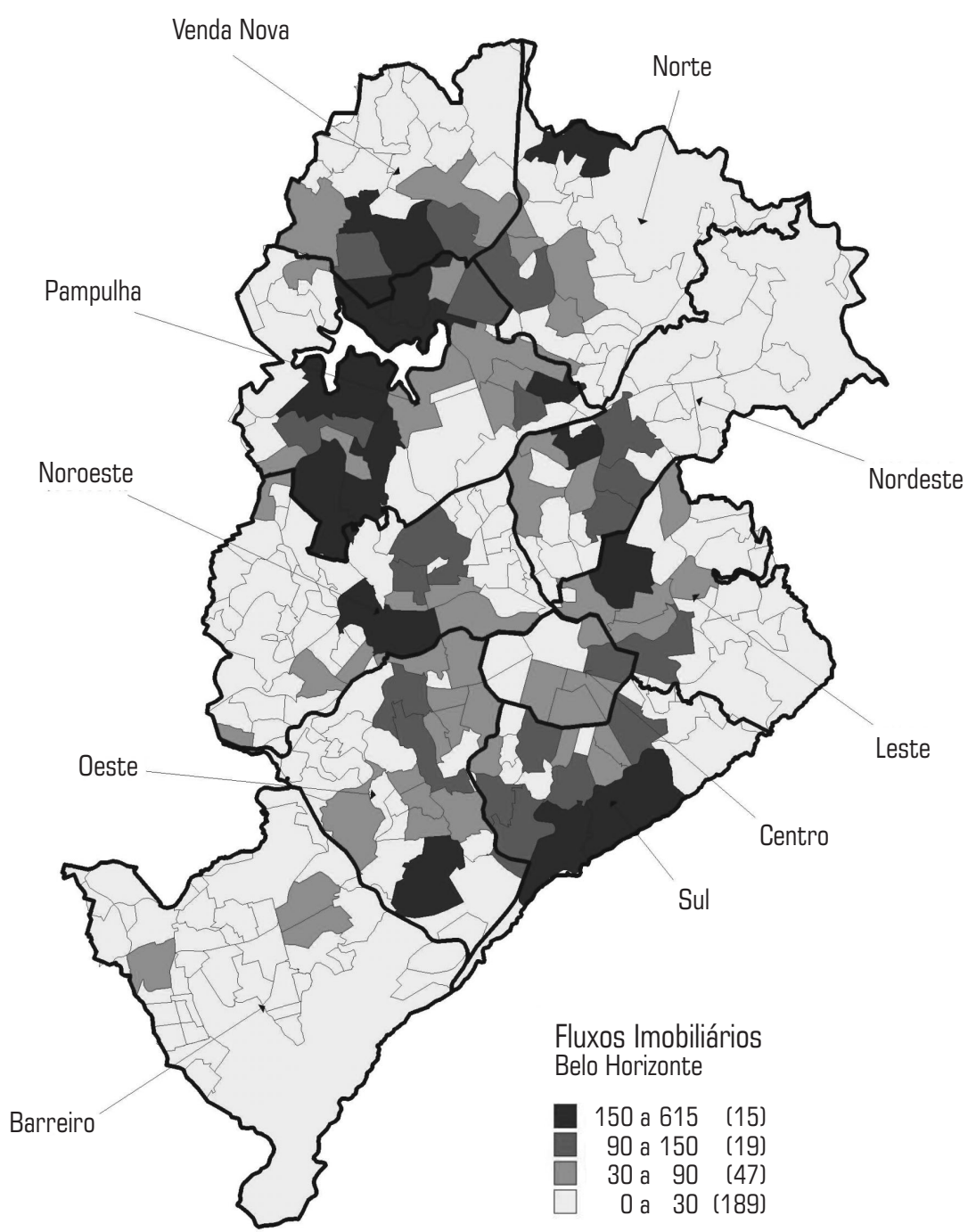

Fonte: Centro de Estudos de Criminalidade e Segurança Pública da Faculdade de Filosofia e Ciências Humanas da UFMG (CRISP/FAFICH/UFMG). Elaborado por Bráulio Figueiredo Alves da Silva a partir dos dados da SMRU/PBH. 
Figura 3_ Transações Imobiliárias de Belo Horizonte 1994-2003

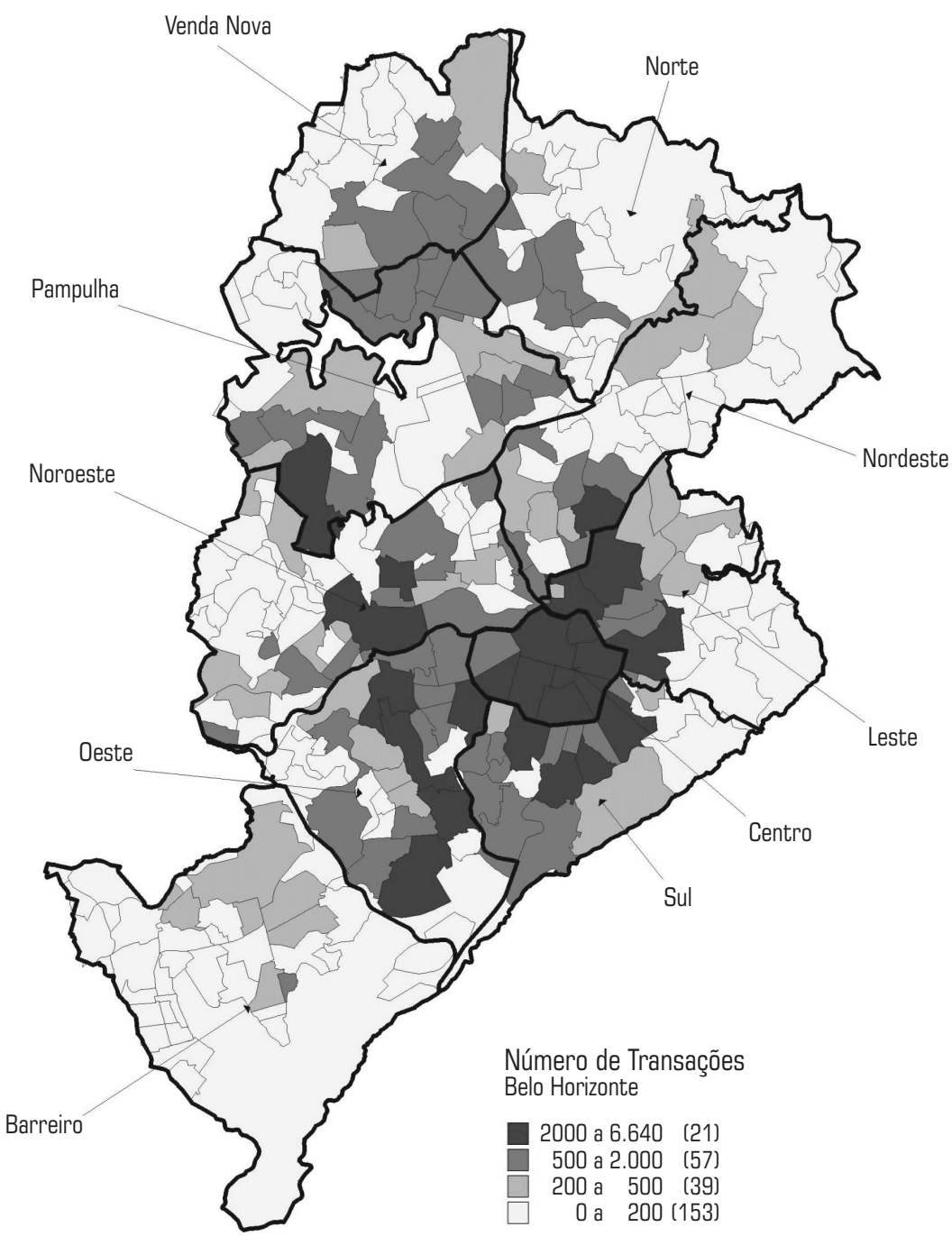

Fonte: Centro de Estudos de Criminalidade e Segurança Pública da Faculdade de Filosofia e Ciências Humanas da UFMG (CRISP/FAFICH/UFMG). Elaborado por Bráulio Figueiredo Alves da Silva a partir dos dados da PRODABEL/PBH - ITBI. 